\title{
Endodontic treatment of a mandibular hypertaurodontic second molar
}

\author{
Tratamento endodôntico de segundo molar inferior com hipertaurodontia
}

Emmanuel João Nogueira Leal SILVA'

Plínio Mendes SENNA'

Tauby de Souza COUTINHO FILHO²

Renato Liess KREBS 2

\begin{abstract}
Taurodontism is the consequence of a developmental disorder in which the invagination of Hertwig's epithelial root sheath doesn't occur at a proper level. As a result, the pulp body and the chamber of a multi-root tooth, usually permanent molar teeth, are enlarged by the apical displacement of the pulp floor. Despite its clinically normal appearance, the morphological variation of this tooth can be diagnosed by a routine radiographic exam that shows enlarged apico-occlusal pulp chamber and short roots. Due to these anatomical variations, endodontic treatment of a taurodontic element is a clinical challenge given the complexity of localization and instrumentation of the root canal system. According to the degree of displacement of the pulp floor, taurodontism can be classified as: hypotaurodontism, mesotaurodontism and hypertaurodontism. This study objective is to report a clinical case of a patient who was submitted to endodontic treatment of the second inferior molar affected by hypertaurodontism.
\end{abstract}

Indexation terms: Endodontics. Mouth abnormalities. Pulp cavity.

\section{RESUMO}

A taurodontia é consequência de um distúrbio de desenvolvimento em que a bainha epitelial de Hertwig não invagina corretamente em um nível normal, repercutindo em um aumento do corpo e da câmara pulpar de um dente multiradicular, predominantemente molares permanentes, pelo deslocamento do assoalho pulpar no sentido apical. Apesar de clinicamente aparentar-se como um dente normal, esta variação morfológica pode ser diagnosticada por exame radiográfico de rotina evidenciando câmara pulpar aumentadas em tamanho no sentido ápico-oclusal e raízes curtas. Devido a estas alterações anatômicas, o tratamento endodôntico de um elemento com taurodontia se torna um desafio clínico, já que é necessário um cuidado especial na localização e manejo do sistema de canais radiculares. De acordo com o grau de deslocamento apical do assoalho pulpar, a taurodontia pode ser classificada em: hipotaurodontia, mesotaurodontia e hipertaurodontia. O objetivo deste trabalho é relatar o caso clínico de um paciente que necessitou de tratamento endodôntico em um segundo molar inferior com hipertaurodontia.

Termos de indexação: Endodontia. Anormalidades da boca. Cavidade pulpar.

\section{INTRODUCTION}

Taurodontism is related to a developmental disorder in which the horizontal invagination of Hertwig's epithelial root sheath doesn't occur at a proper level. As a result, the tooth lacks constriction at the junction of the amelocement (JAC) with short roots and a pulp chamber elongated by apical displacement of the chamber floor ${ }^{1}$. Root bifurcation or trifurcation is commonly found at the apical level ${ }^{2-3}$, which makes difficult the access to the root canals and full elimination of infected tissues of the canal system ${ }^{4}$, thus it can be considered an endodontic challenge.
This alteration is asymptomatic and the tooth seems to be clinically normal, given that JAC is hidden by the gingiva and the bone symphysis ${ }^{5}$. Therefore, a clinician may be astonished to find a tooth affected by taurodontism during an endodontic treatment. Its incidence affects $11.3 \%$ of the population ${ }^{6}$ and, although it is an isolated anomaly, it can be related to syndromes and other developmental anomalies such as imperfect amelogenesis, ectodermic dysplasia, Down syndrome, Klinefelter syndrome, thricodentalosseous syndrome, Mohr syndrome, Wolf-Hirschhorn syndrome and Lowe syndrome ${ }^{6}$.

\footnotetext{
${ }^{1}$ Universidade do Grande Rio (Unigranrio) Rua Herotides de Oliveira 61/902, Icaraí, 24230-230, Niterói, RJ, Brasil. Correspondência pra / Correspondence to: EJNL SILVA. E-mail: <nogueiraemmanuel@hotmail.com>.

${ }^{2}$ Universidade do Estado do Rio de Janeiro, Faculdade de Odontologia. Rio de Janeiro, RJ, Brasil.
} 
Taurodontism diagnosis is performed by radiographic exams. In the periapical radiograph, this alteration can also be classified by the vertical position of the pulp floor (Figure 1), as in hypotaurodontism, a less severe form which presents augmented pulp chamber without affecting the roots.

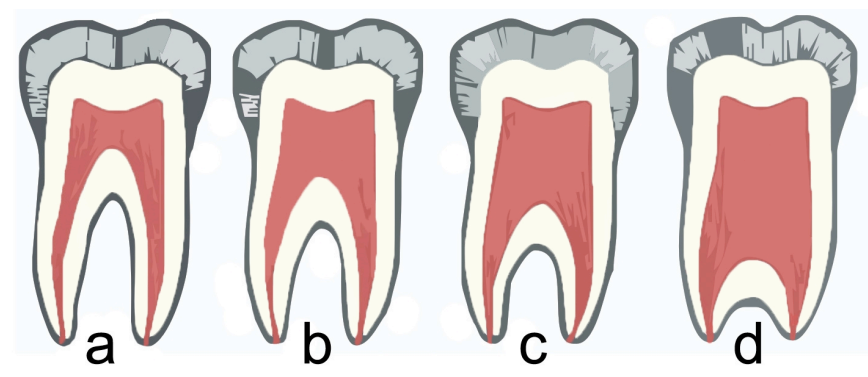

Figure 1. Taurodontism classification normal tooth; B) hypotaurodontism; C) mesotaurodontism; D) hypertaurodontism

In mesotaurodontism, there is a greater increment of the pulp chamber with shorter roots, but they remain separated. Hypertaurodontism is the most severe form that presents bifurcation or trifurcation of the root apical third which hampers the localization and access to the canals ${ }^{7-8}$. In this clinical case, it is described the endodontic treatment of a hypertaurodont second inferior molar.

\section{CLINICAL CASE}

A melanodermatous female patient, 33 years old, arrived at the graduate clinic of Endodontics of Universidade do Estado do Rio de Janeiro (UERJ) for endodontic treatment of the left inferior second molar. The patient's medical record did not indicate any systemic alteration.

The intraoral exam revealed a cavity produced by a carious lesion in this mesial tooth which presented no sensitivity to percussion or palpation and, periodontal normality $(2-3 \mathrm{~mm})$ in the depth probing. Subsequently, a periapical radiograph of the tooth showed a pulp chamber that extended to beyond the cervical area in the furcular region at the apical level and two short roots (Figure 2). This tooth was then classified as affected by hypertaurodontism and, the contralateral tooth also presented the same alteration in the confirmatory periapical radiograph.

The patient was anesthetized by blockage of the left inferior alveolar nerve with lidocaine $2 \%$ and epinephrine 1:100,000 (Alphacaine 100, DFL; Rio de Janeiro, Brazil). Surgical microscopy was employed to enable visualization of details. The element was isolated and access was accomplished.

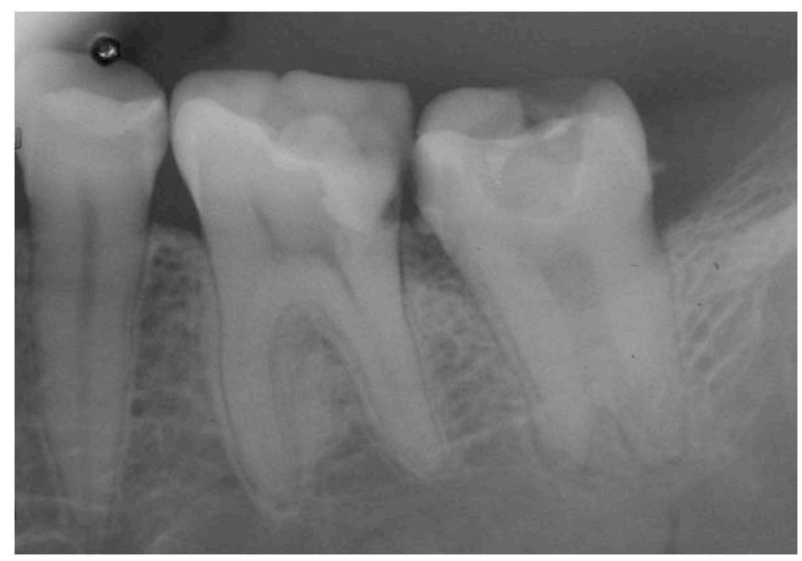

Figure 2. First radiograph.

Pulp was exposed and profuse bleeding was observed and controlled through abundant irrigation with sodium hypochlorite at $5.25 \%$. Two canals were found: one mesial and the other one distal. Odontometry was performed with instruments \#10 and confirmed through a foraminal localizer (Novapex, Endovita; São Paulo, Brazil). After determining the working length, both canals were instrumented up to file \#40. Crown-down technique was employed to perform instrumentation of the canals with manual files. Irrigation with $1 \mathrm{ml}$ of $5.25 \%$ sodium hypochlorite was applied to the canal area whenever a file was substituted.

After the canals were dried, a medium cone calibrated in accordance with the last lime was placed in the canal interior with cement Pulp Canal Sealer (SybronEndo; Orange, California, USA), and a hybrid technique of lateral condensation with vertical pressure using thermal plasticization (Touch'n heat 5004, SybronEndo; Orange, California, USA). This procedure was followed by a backfill performed with the system Obtura II (Spartan; Fenton, Missouri, USA). The final radiograph showed good condensation and sound obturated canals. Moreover, another canal that was previously overlooked was filled (Figure 3).

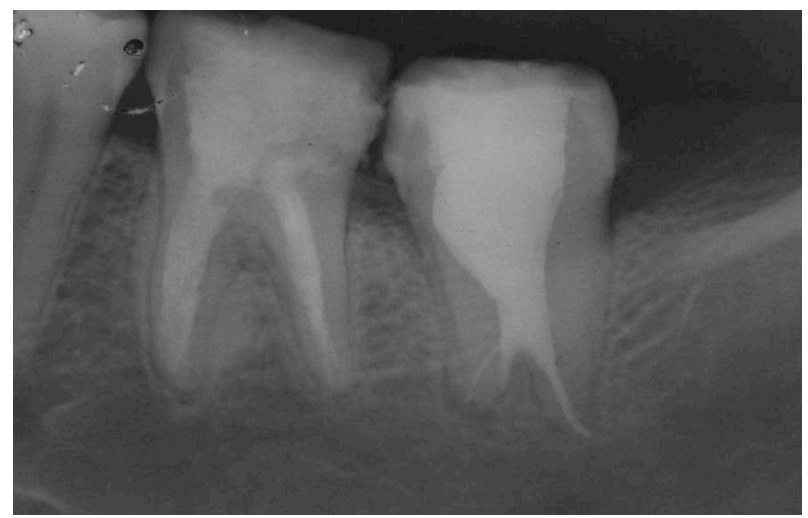

Figure 3. Last radiograph. 


\section{DISCUSSION}

The term taurodontism was introduced by Arthur Keith in 1913 due to its similarity to bull teeth 9 . Initially, it was believed that the most severe forms were absent in man of modern times. Notwithstanding, there are reports that confirm taurodontism in permanent dentition ${ }^{10}$, deciduous dentition ${ }^{11}$ or both concurrently ${ }^{12-13}$. However, inferior molars are commonly affected, and $91 \%$ of the cases are bilateral ${ }^{14}$. In this patient, the second inferior molars were bilaterally affected.

Taurodontism refers to a condition in which the pulp chamber is vertically larger due to the floor apical displacement. However, other metabolic conditions such as hypophosphatasia, pseudo-hypoparathyroidism and, hypophosphatemia resistant to vitamin $\mathrm{D}$ and rickets dependent can trigger the growth of the pulp chamber without significant floor dislodgement which maintains its normal general aspect ${ }^{15}$. Thus, a periapical radiograph, together with the patient's medical records, is vital for a proper diagnosis given that several syndromes may be associated to taurodontism ${ }^{4}$. Despite the possibility of its association to several developmental syndromes and anomalies, this female patient was healthy and had no reported medical alterations.

Taurodontic teeth may present wide-ranging variations with regard to the pulp chamber, obliteration levels, canal configuration and apical positioning in the canal entry orifices. Hence, endodontic therapy is a challenging task in these cases $^{16}$. Due to the pulp large volume, it has been suggested, in order to carry out the full removal of necrotic remnants, the utilization of sodium hypochlorite at $2.5 \%$ to dissolve the pulp tissue ${ }^{17}$. Moreover, given the unpredictability of the instrumentation of a taurodontic tooth irregular radicular canal system, Widerman \& Serene ${ }^{18}$ suggested an additional effort with copious irrigation with sodium hypochlorite at $2.5 \%$ for maximum dissolution of necrotic material. In this case $5.25 \%$ sodium hypochlorite was employed as an attempt to remove most of the necrotic tissue.

\section{REFERENCES}

1. Hamner JE, Witkop CJ Junior, Metro PS. Taurodontism: report of a case. Oral Surg Oral Med Oral Pathol. 1964;18: 409-18.

2. Brkic H, Filipovic I. The meaning of taurodontism in oral surgery: case report. Acta Stomatol Croat. 1991;25(2):123-7.
Taurodontism represents a challenge throughout negotiation, instrumentation and obturation of the endodontic therapy. Mesial and distal orifices were very close, which hampered localization of and negotiation with these canals. Given the tooth complex anatomy in this clinical case, only the apical third was submitted to instrumentation. Moreover, it was necessary to gather the techniques of obturation, lateral condensation and vertical compression using a thermal plasticizer and, for the backfill; the Obtura II system provided excellent results, as shown in the postoperative radiographs.

The success in this case was most of all due to the use of microscopic magnification that allowed the localization of two canals, facilitating negotiations, instrumentation and obturation of the canals. The patient returned three months later for reassessment and was referred to the department of Dental Prosthesis for the element rehabilitation treatment.

\section{CONCLUSION}

The actual case presents the treatment of hypertaurodont molar tooth. Despite the challenging endeavor for endodontists, the clinical case suggests that endodontic treatment of taurodontic teeth is possible. Success can be mostly associated to an adequate treatment plan associated to magnification that allowed proper identification and instrumentation of the radicular canal system. Thus, it can be concluded that magnification was of great importance in the conduction of the endodontic treatment and prediction of the treatment successful outcome.

\section{Collaborators}

EJNL SILVA and PM SENNA performed the endodontic and prosthetic treatment of the patient and authored the article. TS COUTINHO FILHO and RL KREBS supervised the clinical procedure and participated in the article writing.

3. Rao A, Arathi R. Taurodontism of deciduous and permanent molars: report of two cases. J Indian Soc Pedod Prev Dent. 2006;24(1):42-4.

4. Jafarzadeh H, Azarpazhooh A, Mayhall JT. Taurodontism: a review of the condition and endodontic treatment challenges. Int Endod J. 2008;41(5):375-88. doi: 10. 1111/j. 1365-2591. 2008. 01388. $x$ 
5. Terezhalmy GT, Riley CK, Moore WS. Clinical images in oral medicine and maxillofacial radiology. Taurodontism. Quintessence Int. 2001;32(3):254-5.

6. Joseph M. Endodontic treatment in three taurodontic teeth associated with 48, XXXY Klinefelter syndrome: a review and case report. Oral Surg Oral Med Oral Pathol Oral Radiol Endod. 2008;105(5):670-7. doi: 10. 1016/j. tripleo. 2007. 11. 015

7. Bharti R, Chandra A, Tikku AP, Wadhwani KK. Taurodontism an endodontic challenge: a case report. J Oral Sci. 2009;51(3):4714. doi: 10. 2334/josnusd. 51. 471

8. Shaw JC. Taurodont teeth in South African Races. J Anat. 1928;62(Pt 4):476-98.

9. Keith A. Problems relating to the teeth of the earlier forms of prehistoric man. Proc R Soc Med. 1913;6 (Odontol Sect): 103-24.

10. Ruprecht A, Batniji S, el-Neweihi E. The incidence of taurodontism in dental patients. Oral Surg Oral Med Oral Pathol. 1987;63(6): 743-7.

11. Fuks $A B$, Chosack $A$. Taurodontism: clinical management and report of case. ASDC J Dent Child. 1983;50(4): 296-9.

12. Goldstein E, Gottlieb MA. Taurodontism: familial tendencies demonstrated in eleven of fourteen case reports. Oral Surg Oral Med Oral Pathol. 1973;36(1):131-44. doi: 10. 1016/00304220(73)90274-0
13. Mena CA. Taurodontism. Oral Surg Oral Med Oral Pathol. $1971 ; 32(5): 812-23$.

14. Laatikainen T, Ranta R. Taurodontism in twins with cleft lip and/or palate. Eur J Oral Sci. 1996;104(2 ( Pt 1)):82-6. doi: 10. 1111/j. 1600-0722. 1996. tb00050. x

15. Gharagozloo S, Faraghat S, Jafarzadeh H. Endodontic treatment of a mesotaurodont maxillary first molar: a case report. N Z Dent J. 2009;105(3): 87-9.

16. Tsesis I, Shifman A, Kaufman AY. Taurodontism: an endodontic challenge. Report of a case. J Endod. 2003;29(5):353-5.

17. Prakash R, Vishnu C, Suma B, Velmurugan N, Kandaswamy D. Endodontic management of taurodontic teeth. Indian J Dent Res. 2005;16(4):177-81. doi: 10. 4103/0970-9290. 29900

18. Widerman FH, Serene TP. Endodontic therapy involving a taurodontic tooth. Oral Surg Oral Med Oral Pathol. 1971;32(4): 618-20. doi: 10. 1016/0030-4220(71)90328-8

Received on: 5/4/2010 Final version resubmitted on: 14/1/2013 Approved on: 19/1/2013 